Nidhomul Haq: Jurnal Manajemen Pendidikan Islam

Accredited Ristekdikti: 28/E/KPT/2019

pp: $144-162$

DOI: https://doi.org/10.31538/ndh.v6i1.1341

http://e-journal.ikhac.ac.id/index.php/nidhomulhaq

\title{
MANAGEMENT EDUCATIONAL INFORMATION SYSTEM DURING PANDEMIC COVID-19 THROUGH TEACHERS' PROFESSIONALISM AND PEDAGOGIC
}

\author{
Dinar Roudhotul Lailia 1), Eni Fariyatul Fahyuni 2), Moch. Bahak Udin By Arifin 3) \\ 1) Universitas Muhammdiyah Sidoarjo. Indonesia \\ email: dinar.lailia@gmail.com \\ ${ }^{2}$ Universitas Muhammdiyah Sidoarjo, Indonesia \\ email: eniumsida@gmail.com \\ ${ }^{3}$ Universitas Muhammdiyah Sidoarjo, Indonesia \\ email: bahak.udin@umsida.ac.id
}

\begin{abstract}
Abstrak
Manajemen sistem informasi pendidikan merupakan pengelolaan dan pemanfaatan teknologi informasi dan komunikasi (TIK) dalam bidang pendidikan atau e-Education. Manajemen sistem informasi pendidikan memberikan kontribusi guna memudabkan tugas-tugas yang dilakukan oleh seluruh tenaga pendidik selama masa pandemic yang terjadi di Indonesia. Penelitian ini merupakan penelitian kuantitatif dimana tujuan penelitian ini untuk mengetabui apakah ada pengarub dari implementasi manajemen sistem informasi pendidikan terbadap kompetensi profesionalisme dan pedagogic guru yang di lakukan di MI Muslimat NU Pucang dan SD Muhammadiyah 1 Pucanganom Sidoarjo. Dalam prosesnya, penelitian ini melakukan teknik pengumpulan data berupa kuisioner, wawancara dan observasi. Pengelolaan data yang di dapat dari hasil pengumpulan data di kelola menggunakan teknik. kuantitatif melalui pengelolaan uji statistic menggunakan SPSS versi 19. Diketabui dari hasil uji regresi dari analisis hasil penelitian menunjukkan bahwa nilai t pada table sebesar 1,993, untuk kompetensi profesionalisme t hitung sebesar 4,540 maka $(4,540>1,993)$ dan kompetensi pedagogic t hitung sebesar 4.030 maka $(4.030$ > 1,993). Jadi dapat disimpulkan bahwa Ho di tolak, bal tersebut menyatakan babwa manajemen sistem informasi pendidikan berpengarub terbadap kompetensi profesionalisme dan pedagogic gurudi MI Muslimat NU Pucang dan SD Mubammaidyah 1 Pucanganom Sidoarjo.
\end{abstract}

Kata Kunci: Manajemen Sistem Informasi Pendidikan, Kompetensi Profesionalisme, Kompetensi Pedagogik

\begin{abstract}
Management of education information systems is the management and utilization of information and communication technology (ICT) in education or e-Education. The management of the education information system has contributed to facilitating the tasks carried out by all teaching staff during the pandemic that occurred in Indonesia. This research is a quantitative study where this study aims to determine whether there is an effect of implementing education information system management on the professionalism and pedagogic competence of teachers in MI Muslimat NU Pucang and SD Muhammadiyah 1 Pucanganom Sidoarjo. In the process, this study conducted data collection techniques in questionnaires, interviews, and observations. Data management obtained from data collection results is managed using quantitative techniques through statistical test management using SPSS version 19. It is known from the results of the regression test from the analysis of the research results showing that the $t$ value in the table is 1.993 , for professional competence $t$ count is 4.540 then $(4,540>1,993)$, and the pedagogic competence $t$ count is 4,030 then $(4,030>1,993)$. So it concluded that Ho is rejected. It states that the education information system's management affects teachers' professionalism and pedagogic competence at MI Muslimat NU Pucang and SD Muhammaidyah 1 Pucanganom Sidoarjo.
\end{abstract}

Keywords: Educational Information Systems Management, Professionalism Competencies, Pedagogical Competencies 


\section{INTRODUCTION}

Education is process to educate people in developing and improving their abilities, attitudes, and behavior to be applied to their environment. (Fattah, 2013, pp. 38-39). Islamic education aims to educate and instill Islamic values in students to improve morals to reach the category of akhlakul karimah. (Syar'i, 2005, p. 28), it is also written in the content of surah al-Baqarah (2) verse 201:

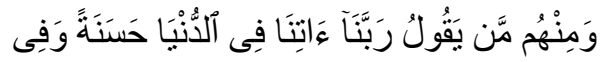

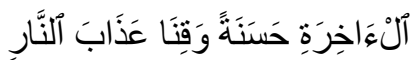

"Yet there are others who say, "Our Lord! Grant us the good of this world and the Hereafter, and protect us from the torment of the Fire."'.

Teachers have an important role in giving birth to a generation that is educated and dignified. Teacher professionalism and pedagogy are a must. It makes teacher competence an absolute requirement to support the teaching and learning process. The qualities that teachers have should be prioritized in the development of an effective educational process. The qualities of a teacher are generally marked by intelligence, dedication, high loyalty and dexterity, and sincerity to reach Allah's pleasure in the process of advancing, educating, and educating all students.

According to Permendiknas No.16 Year 2007, there are four core competency standards for teachers, two of which are professional competence and pedagogical competence. Teacher professionalism is a must for a teacher. Muhaimin explained that professional competence is determined by three important factors, namely: (1) having special skills that have been prepared in educational programs and even specializations (2) the abilities that are owned are the abilities that are used to improve (3) sufficient income as a reward for expertise which is owned. Barizi explained that a professional attitude is something that teachers must have to educate students' personalities, and teachers are required to understand and master the fields they are qualified for.(Barizi, 2009, p. 123)

Professionalism is a skill of someone as a reflection of their quality, as well as the professional competence of teachers, which is the ability of an educator to master their field by mastering teacher tasks and being able to transfer their knowledge to students properly so that they can help students in understand and have the competence required (Asmani, 2009, p. 158; Van Dyk et al., 2020, p. 19).

Teacher's pedagogical competence is inseparable from the term teacher professional competence. Pedagogic competence is an ability possessed by teachers to manage a learning process that includes students 'understanding, design, implementation, evaluation, and development of student's abilities in a lesson. Pedagogic teacher competencies also include mastery of 
knowledge and teaching skills so that teachers are said to be ready to teach (Sirotová, 2016, p. 20).

Given the professionalism and pedagogical competence of teachers are important factors in improving the quality of education (Ismail et al., 2020; Pakpahan \& Habibah, 2021). Various efforts to improve teacher professionalism and pedagogical competence include seminars, training, upgrading, and educational information systems. Law also supports this no. 14 of 2005 concerning Teachers and Lecturers, where competence is an integration of knowledge, skills, and behavior that are possessed by teachers and can be lived and controlled by teachers and lecturers in carrying out professional tasks. ('UU RI No 14 Thn Tentang Guru Dan Dosen', 2005)

$$
\text { Besides, maximizing teachers' }
$$
professionalism and pedagogic competence cannot be separated from management's main points, including planning to optimize teachers' professional competence and pedagogic competence, organizing to realize planned activities by determining activities to be carried out managerially, actuating used to direct educators to carry out activities according to what has been planned, and controlling process that is useful for activities carried out following the plan and the achievement of predetermined results (Fattah, 2013, p. 2).
In the current pandemic that is befalling the whole world, it is urgent to make humans keep a distance from each other to reduce the risk of contracting Covid-19. Information systems (digital) serve as a bridge to assist all sectors in carrying out their activities. One of the sectors that have been heavily influenced during this pandemic is the education sector. Education in Indonesia is generally accustomed to face-to-face activities with students and being present at institutions as a form of daily activities. The education information system is the key to supporting teaching and learning activities and WFH (work from home) activities (Aji, 2020, pp. 397-388; Maqsood et al., 2021, p. 23). In today's digital era, information systems in education have an important role in managing and making it easier for information to be integrated, effective, efficient, and accountable for managerial and operational needs (Prasojo, 2013, p. 9).

The management of the education information system carried out by the government, and the school itself is expected to provide convenience and positive influence and improve teachers' core competencies (Firma Sahrul B, 2017, p. 47). Through research conducted by Muhaimin, data on the quality of teachers in Indonesia shows that approximately $50 \%$ of teachers in Indonesia do not yet have the quality that is following the national education standard (SPN) (Muhaimin, 2012, p. 191). Described in the Human 
Development Index (HDI) records in 2020, Indonesia was ranked 111, and also explained in the Global Talent Competitiveness Index (GTCI), Indonesia was ranked 65th. Muhaimin stated that the quality of teachers in Indonesia is inadequate. There are $60 \%$ of elementary school teachers deemed unfit to teach at their respective levels from the HDI statistics (Muhaimin, 2012). Data from the Regional Education Balance (NPD) per 2019 in East Java Province stated that $46.8 \%$ of elementary school teachers were not certified or did not meet professional standards. Supported by research conducted by Leonard, the study examined approximately 60 teachers in Jakarta. It stated that $75 \%$ of teachers did not prepare to learn well where the teachers only focused on the material and system, not on the goals to be achieved.(Leonard, 2016, p. 193)

During this pandemic, technological advances are very influential in all fields, including education. Many things are done to manage an institution to achieve quality effectively and efficiently, including optimizing educational information systems (Munjiat, 2020). The educational information system is part of the use of information and communication technology in education. Educational information systems can influence many things, including improving the quality of education, overcoming gaps, and developing a dynamic social life.(Sonhaji, 2014, p. 53)
The purpose of this study is used to determine the application of management educational information system which influences the professional competence and pedagogical competence of teachers at MI Muslimat NU Pucang because MI Muslimat NU Pucang on 20th January 2017, has the category "The Most Islamic School of The Year" in the Indonesia Best of The Best Award event. According to Islamiyah's research, all teachers at MI Muslimat NU are multi-talented. All teachers have 44\% S1 and $56 \%$ S2 and have Cambridge International Certification Trainer of Teacher certificates, $20 \%$ of teaching staff are nationally certified, and $14 \%$ of educators are internationally certified. Also, MI Muslimat NU implements an educational information system in Google Meet and SIMAS (Madrasah information system).

SD Muhammadiyah 1 Pucanganom Sidoarjo is also one of the favorite Islamic schools in Sidoarjo. In 2018 the school was able to take its students and students to take part in the international mathematics olympiad. Through the ISCM (International Singapore Maths Competition), students were able to win a gold medal on May 3, 2018, and the IMWIC (International Math Wizard Competition) event on 6th May 2018 was able to bring home a silver medal. The success of the students of SD Muhammadiyah 1 Pucanganom Sidoarjo is also inseparable from competent supervisors' role. SD Muhammadiyah 1 Pucanganom itself 
has used an information system in the form of LSM, Muhida Belajar, Zoom meetings, Muhida Radio, CSM cards. Of course, the category in the favorite Islamic school is also influenced by the community's response to the infrastructure and competencies possessed by the educators. This encourages the author to research the two schools to find out how "Implementation of Educational Information System Management on Professionalism Competencies and Teacher Pedagogical Competencies at MI Muslimat NU Pucang and SD Muhammadiyah 1 Pucanganom Sidoarjo."

\section{LITERATUR REVIEW}

\section{Management of educational information systems}

The educational information system itself is a resource that fully participates in building an information society with the information needed for organizing, classifying, obtaining, and conveying good, correct, and responsible information. The education information system is the development and diversity of information in education and forms an activity that runs smoothly and dynamically (B. Uno, Hamzah \& Lamatenggo, 2010, p. 58; Echeverría et al., 2012, p. 25).

Management of educational information systems is the management and use of information and communication technology (ICT) in education or often referred to as eEducation. Management of educational information systems is the use of information technology to contribute to facilitate the tasks performed by all educators. In the world of education, the education information system is mentioned in three ways: First, the education information system is an information and communication technology (ICT) in the form of technology products used in the world of education. Second, educational information systems are used to learn material content and be used as learning content in the learning process. Third, the education information system can be an application program and a tool to help the education management process so that it becomes effective and efficient. Information system management in education also pays attention to several aspects, including IT development, IT platforms in hardware and software, databases, data security, and consumer needs. This means that information resources emphasize management, development, and skills in using information systems (B. Uno, Hamzah \& Lamatenggo, 2010, p. 58)

This pandemic era requires educational organizations to do more work. Therefore, an educational organization needs a good educational information system management to optimize the education information system as a supporting tool for the continuation of teaching and learning activities and as a driving tool for the management of educational organizations. There are several problems 
behind the use of educational information systems in the world of education, including; (1) the increasing number of cases of the Covid-19 pandemic, which demands to carry out PJJ to reduce transmission,(Aji, 2020, p. 399; Aslan et al., 2020, p. 322; Maqsood et al., 2021, p. 28) (2) improve the quality of all levels of education, (3) address gaps that occur in the world of education caused by geographical conditions, if neglected matters this can have an impact on disparities in service quality. (4) Changes in the cultural behavior of the community that moves dynamically (Noraziah et al., 2011, p. 22; Sonhaji, 2014, p. 50).

Information is an essential resource in the management of an educational information system. Management of information resources in education is the key to achieving goals that educational organizations have initiated. Resources that are educational information resources include: (a) content and curriculum used by schools, (b) teaching and learning process activities, (c) facilities and infrastructure provided by schools, (d) human resources. The four resources are described in the National Education Standards (SNP)(Sonhaji, 2014, pp. 133-134)

Some of the uses and functions of information system management, among others; (1) increase data accessibility quickly and accurately for users. (2) Ensuring the quality and skills in the use of information systems. (3) Help develop an effective institutional planning process. (4) Helps in identifying organizational needs. (5) determine the referenced investment in information systems (6) anticipate and understand the economic consequences of new information systems and technology (7) improve productivity in system development and maintenance applications (Rochaety, 2011, pp. 9-12; Sayed et al., 2018, p. 32).

The education information system management objectives include: (1) a role to assist all parts that play a role in education by providing comprehensive information related to education from elementary to tertiary level. (2) is public accountability by providing transparent information relating to policies and the use of all resources allocated to the world of education. (3) To provide facilities for all parts of the teaching force who play a role in the world of education, both in provinces, cities, and districts, they can play an active role in efforts to advance education. (4) Increasing the knowledge of all educators and students about the world of informatics and its use can be obtained from several training pieces. (5) Provide easy and complete access to information for all educators and students about science and educational information (Rochaety, 2011, p. 24).

Implementation of education information system management is intended to support management activities used to support the achievement of educational organizations' 
targets and operational functions. With the existence of an education information management system, educational organizations will benefit as follows: First, the availability of a data and information management system in education. Second, educational data and information are integrated to support processes in decision-making. Third, the availability of complete education data and information for all stakeholders involved in the education sector. Fourth, increasing flexibility. Its users can use the educational information system to make decisions, and the parties that are joined (stakeholders) can interact with educational organizations (Echeverría et al., 2012, p. 23; Sutabri, 2012, p. 158).

\section{Professionalism Competence}

Since humans' birth has colored activities in the world, in this global era, education is essential in social life. Where it becomes a force to keep pace with the development of science and technology, looking further towards the determinants of educational success cannot be separated from the role of a "teacher." The involvement of a teacher in learning is also an important aspect of achieving educational success. According to Barizi, a teacher is a spiritual sage who fills himself with knowledge, and a teacher is also a person who loves his children (students)(Barizi, 2009, p. 131). According to Asmani, teachers are a noble profession. Teachers also play an important role in giving birth to a generation and determining the human journey Asmani, 2009, p. 38; Demirkasimoğlu, 2010, p. 33).

Based on Law no. 14/2005 concerning teachers and lecturers in article 1 paragraph 1 , describes teachers as: "professional educators with the main task of educating, teaching, guiding, directing, training, assessing, and evaluating students in early childhood education through formal education, basic education, and secondary education (Hartono, 2011, p. 53; Nurulloh et al., 2020, p. 336).

Kunandar stated that professionalism is the condition, objective value, and quality of expertise and authority related to one's livelihood (Kunandar, 2009, p. 46). According to Asmani, teacher professionalism is a must. Competence is an absolute prerequisite for professionalism. Without teachers' professionalism, it is feared that they will not be able to achieve the goals they carry in guiding students towards the future. Asmani also explained in his book that a teacher is a uswatu hasanah even though he is not as perfect as the Prophet. Professional teachers are those who are ready to provide high moral guidance to their students.(Asmani, 2009, pp. $37 \& 115)$

Muhaimin explained that professionalism determined by three factors, including (1) having special expertise and being prepared by a specialization or expertise education 
program. (2) The ability to improve the quality of oneself (3) a balanced income as a reward given to their expertise. According to Muhaimin, the teacher's image and dignity explain that professionals designate two things, namely people and their performance in carrying out their duties and jobs. In comparison, professionalism refers to the level of performance in carrying out a noble profession (Muhaimin, 2012, p. 181).

Barizi explained that a professional attitude is something that teachers must possess to educate students' personalities, and teachers are required to understand, understand, and master the fields they are qualified for (Barizi, 2009, p. 132).

In the National Education Standards, the explanation of paragraph 28 paragraph 3 point (C) states that the professional competence of teachers is the mastery of subject matter broadly and deeply, which is used to guide students in meeting the competency standards that have been set in the National Education Standards (SNP).

\section{Pedagogic Competence}

Teacher professional competence is related to teacher pedagogic competence. Pedagogic competence is the ability to manage to learn. This includes teaching readiness aimed at mastery of knowledge and skills in teaching. Pedagogic competence in the national education standards in the explanation of article 28 paragraph 3 point (a) is "the ability to manage student learning, design, implement learning, evaluate learning outcomes, and develop students to actualize their various potentials."(Asmani, 2009, p. 59)

Pedagogic competence is the teacher's ability to manage learning which includes understanding students, designing and implementing learning, evaluating and developing and guiding students with all their potentialv(Luan et al., 2010, p. 33). In the Teacher and Lecturer Law, pedagogical competence is stated in paragraph 2, which is the ability of teachers to manage the learning of students, including at least: "Understanding of educational insight or foundation. Understanding of students. Curriculum or syllabus development. Learning design. Educational and dialogical implementation of learning. Utilization of learning technology. Evaluation of learning outcomes and development of students to actualize their various potentials. "Pedagogic competence is a teacher's way of teaching and managing a learning system with good interaction with students and mastery of learning to help students understand the material provided(Asmani, 2009, p. 60).

The previous study that written by Khairul Imtihan (Imtihan, 2015, p. 7) under the title "Strategic Planning of Educational Information Systems at the College of 
Informatics and Computer Management (STEMIK) Lombok" states that strategic planning of information systems has been used to analyze the internal environment in educational operations so that it can be known the need for educational information systems in the data processing. Strategic education operations to plan future documentation to increase the excellence of a more competitive institution.

Research is written by Firma Syahrul entitled "implementation of academic information system web-based using framework laravel" states that in research activities on the Implementation of Academic Information Systems as an effort to monitor students' academic, it concluded that the use of the Laravel framework could meet all the needs in making Academic Information Systems. (Firma Sahrul B, 2017, p. 48).

"Web-Based Educational Information System for enhanced Learning, EISEL: Student Assessment" written by George and Molson. In his research, the writer states that information technology is important today, including education. The Web-Based Educational Information system increases the effectiveness of the learning process and facilitates the distance learning process for students. (George Saadé, 2013, p. 6).

\section{RESEARCH METHODOLOGY}

This study using a quantitative research type. Quantitative research is research that is focused on the study of objective phenomena to be studied quantitatively (Musfiqon, 2012, p. 59). The research design used is problem analysis, questionnaire preparation, field testing, data analysis, evaluation.

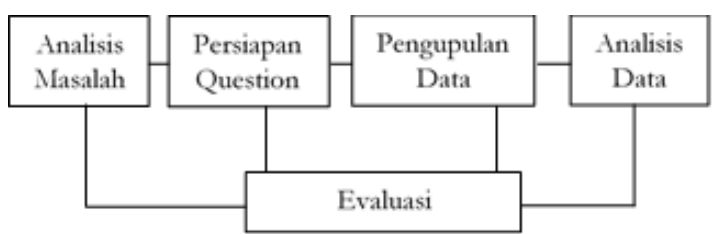

Picture 1. Research design

The population in this study involved teachers at MI Muslimat NU Pucang Sidoarjo consist of 46 teachers and SD Muhammadiyah 1 Sidoarjo consist of 30 teachers. In this study, using a non-probability sampling technique, this technique is commonly called saturated sampling. The saturated sample is the use of the entire population in the research object.

This study uses data collection techniques in unstructured interviews, which are used to dig deeper information about the management of education information systems on teacher professionalism and pedagogic competencies. Observations are used to obtain information or data by direct observation in the field. Researchers gave the questionnaire to teachers to obtain data from the management of the education information system on teachers' 
professionalism and pedagogy at MI Muslimat NU Pucang Sidoarjo and SD Muhammadiyah 1 Pucanganom Sidoarjo. The researcher made 30 statement questions using a Likert scale of 5 answers in the questionnaire form, namely, strongly disagree, disagree, neutral, agree, and strongly agree.

Data processing techniques in this study used SPSS version 19 and Microsoft Excel. The data analysis technique used is inferential

\begin{tabular}{ccl}
\hline No & $\begin{array}{l}\text { Correlation } \\
\text { coefficient }\end{array}$ & \multicolumn{1}{c}{ Explanation } \\
\hline $\mathbf{1}$ & $0,00<\mathrm{r}_{\mathrm{xy}} \leq 0,20$ & $\begin{array}{l}\text { The degree of } \\
\text { validity is very low }\end{array}$ \\
\hline $\mathbf{2}$ & $0.20<\mathrm{r}_{\mathrm{xy}} \leq 0,40$ & $\begin{array}{l}\text { The degree of } \\
\text { validity is low }\end{array}$ \\
\hline $\mathbf{3}$ & $0,40<\mathrm{r}_{\mathrm{xy}} \leq 0,60$ & $\begin{array}{l}\text { The degree of } \\
\text { validity is moderate }\end{array}$ \\
\hline $\mathbf{4}$ & $0,60<\mathrm{r}_{\mathrm{xy}} \leq 0,80$ & $\begin{array}{l}\text { The degree of } \\
\text { validity is high }\end{array}$ \\
\hline $\mathbf{5}$ & $0,80<\mathrm{r}_{\mathrm{xy}} \leq 1,00$ & $\begin{array}{l}\text { The degree of } \\
\text { validity is very high }\end{array}$ \\
\hline
\end{tabular}

statistical analysis. Inferential statistics is an analysis based on the results of the population's treatment and the research sample.

Analyzing the changes found in the sample results by influence analysis techniques

\begin{tabular}{lll}
\hline No & $\begin{array}{l}\text { Correlation } \\
\text { coefficient }\end{array}$ & \multicolumn{1}{c}{ Explanation } \\
\hline $\mathbf{1}$ & $0,00<\alpha \leq 0,20$ & Very low \\
\hline $\mathbf{2}$ & $0.20<\alpha \leq 0,40$ & Low \\
\hline $\mathbf{3}$ & $0,40<\alpha \leq 0,60$ & Moderate \\
\hline $\mathbf{4}$ & $0,60<\alpha \leq 0,80$ & High \\
\hline $\mathbf{5}$ & $0,80<\alpha \leq 1,00$ & Very high \\
\hline (regression). Using regression analysis aims to \\
answer & the problem & formulation. However, \\
before analyzing the effects that occur, the first
\end{tabular}

steps that must be include testing for normality, validity, and reliability

Analysis of the normality test is a test carried out to determine whether or not a data

\begin{tabular}{ccc}
\hline No & $\begin{array}{c}\text { Correlation } \\
\text { coefficient }\end{array}$ & keterangan \\
\hline 1 & $\begin{array}{c}\mathbf{t} \text { table } \leq \mathbf{t} \text { count } \\
\leq \mathbf{t} \text { table }\end{array}$ & Ho Accepted \\
\hline 2 & $\mathbf{t}$ count $<\mathbf{t}$ table & Ho Rejected \\
\hline 3 & $\mathbf{t}$ count $>\mathbf{t}$ table & Ho Rejected
\end{tabular}
distribution is normal. This test is important to do because parametric statistics require that the data be normally distributed. The normality test used is assisted by the SPSS version 19 program.

Table 1 . Normality coefficient

\begin{tabular}{ccl}
\hline No & $\begin{array}{c}\text { Correlation } \\
\text { coefficient }\end{array}$ & \multicolumn{1}{c}{ Explanation } \\
\hline 1 & Sig $<\mathbf{0 , 0 5}$ & $\begin{array}{l}\text { Not normally } \\
\text { distributed }\end{array}$ \\
\hline 2 & Sig $>\mathbf{0 , 0 5}$ & $\begin{array}{l}\text { normally } \\
\text { distributed }\end{array}$ \\
\hline
\end{tabular}

Validity test analysis is used to determine the validity of the results analyzed in the data normality test. The validity test used is assisted by the SPSS version 19 program.

Table 2. Validity coefficient

Reliability test analysis is used to determine the reliability of the results that have been analyzed in the data normality test. The reliability test used is assisted by the SPSS version 19 program

Table 3. Reliability coefficient 
The final analysis carried out in this study

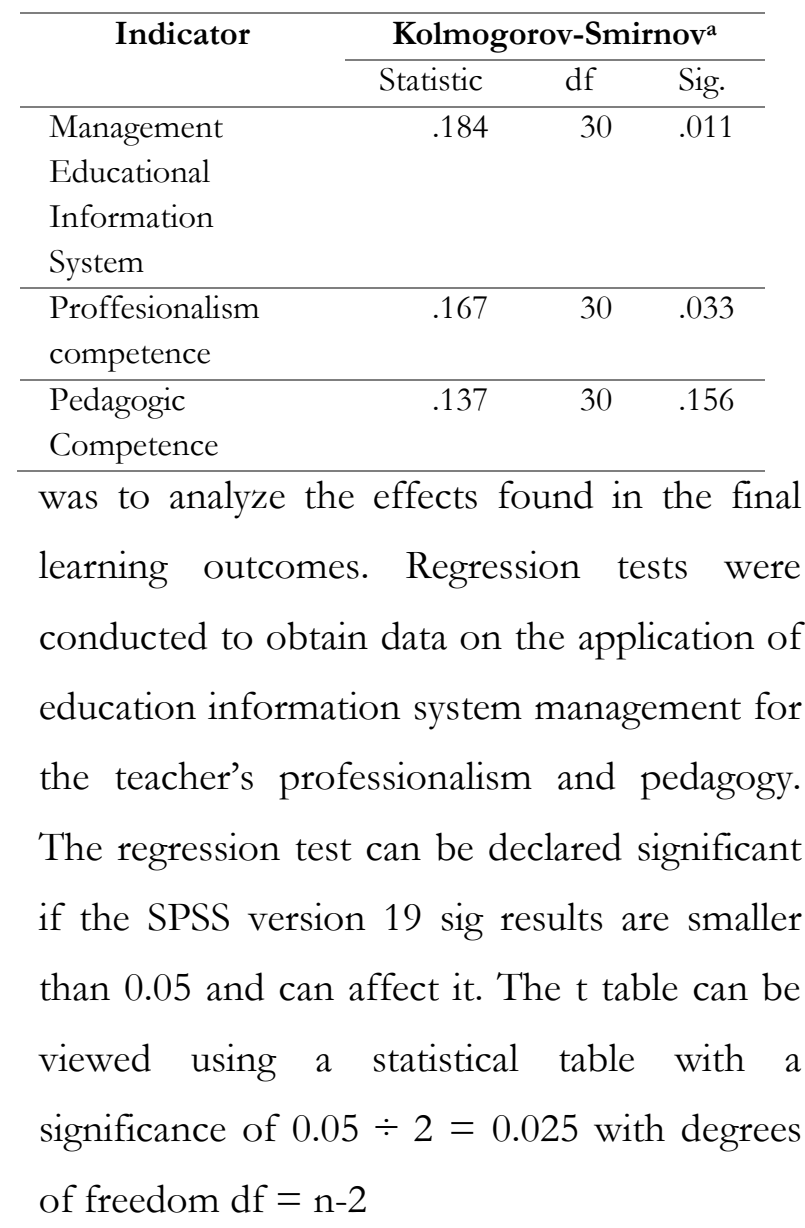

Table 4. Regression coefficient

\section{RESULT AND DISCUSSION}

In this study, researchers conducted data collection techniques through questionnaires which were distributed to 46. Through the collected data, it is known normality test as following:

Table 5. Normality test Mi Muslimat Nu

Through the results obtained from the questionnaire at $\mathrm{MI}$ Muslimat NU, the normality test was carried out using the Kolmogorov-Smirnov formula calculation at the 0.05 significance level. the significance of the education information system management data reaches 0.013. Data from professional competence has a significance of 0.014 and data from pedagogic competence reaching 0.066. This shows that the three data's significance value reaches more than 0.05 , which is stated to be normally distributed. 1

Table 6. Normality test SD Muhammadiyah

The results obtained from the questionnaire at SD Muhammadiyah 1, the significance of the education information system management data reached 0.011 , data from professional competence has a significance of 0.033 , and data from pedagogic competence reached 0.156, this shows the significance value of the three data reaches more than 0.05 which is stated. Normally

\begin{tabular}{lrrr}
\hline \multirow{1}{*}{ Indicator } & \multicolumn{3}{c}{ Kolmogorov-Smirnov ${ }^{\mathbf{a}}$} \\
\cline { 2 - 4 } & Statistic & $\mathrm{df}$ & Sig. \\
\hline Management & .148 & 46 & .013 \\
$\begin{array}{l}\text { Educational } \\
\text { Information } \\
\text { System }\end{array}$ & & & \\
\hline $\begin{array}{l}\text { Professionalism } \\
\text { competence }\end{array}$ & .147 & 46 & .014 \\
\hline $\begin{array}{l}\text { Pedagogic } \\
\text { Competence }\end{array}$ & & & \\
\hline
\end{tabular}
distributed.

Table 7. Validity test

\begin{tabular}{lllrl}
\hline & & Item & & Item \\
& & & & \\
& & total & & total \\
& & & & \\
\hline P1 & PC & $.354^{* *}$ & P16 PC & $.645^{* *}$ \\
& Sig. & .002 & Sig. & .000 \\
\hline
\end{tabular}




\begin{tabular}{|c|c|c|c|c|}
\hline & $\mathrm{N}$ & 76 & $\mathrm{~N}$ & 76 \\
\hline \multirow[t]{3}{*}{ P2 } & PC & $.478^{* *}$ & P17 PC & $.528^{* *}$ \\
\hline & Sig. & .000 & Sig. & .000 \\
\hline & $\mathrm{N}$ & 76 & $\mathrm{~N}$ & 76 \\
\hline \multirow[t]{3}{*}{ P3 } & PC & $.535^{* *}$ & P18 PC & $.629 * *$ \\
\hline & Sig. & .000 & Sig. & .000 \\
\hline & $\mathrm{N}$ & 76 & $\mathrm{~N}$ & 76 \\
\hline \multirow[t]{3}{*}{ P4 } & PC & $.531 * *$ & P19PC & $.562^{* *}$ \\
\hline & Sig. & .000 & Sig. & .000 \\
\hline & $\mathrm{N}$ & 76 & $\mathrm{~N}$ & 76 \\
\hline \multirow[t]{3}{*}{ P5 } & PC & $.539 * *$ & P20 PC & $.420^{* *}$ \\
\hline & Sig. & .000 & Sig. & .000 \\
\hline & $\mathrm{N}$ & 76 & $\mathrm{~N}$ & 76 \\
\hline \multirow[t]{3}{*}{ P6 } & PC & $.400 * *$ & P21 PC & $.692 * *$ \\
\hline & Sig. & .000 & Sig. & .000 \\
\hline & $\mathrm{N}$ & 76 & $\mathrm{~N}$ & 76 \\
\hline \multirow[t]{3}{*}{ P7 } & PC & $.537 * *$ & P22PC & $.559 * *$ \\
\hline & Sig. & .000 & Sig. & .000 \\
\hline & $\mathrm{N}$ & 76 & $\mathrm{~N}$ & 76 \\
\hline \multirow[t]{3}{*}{ P8 } & PC & $.430 * *$ & P23 PC & $.467 * *$ \\
\hline & Sig. & .000 & Sig. & .000 \\
\hline & $\mathrm{N}$ & 76 & $\mathrm{~N}$ & 76 \\
\hline \multirow[t]{3}{*}{ P9 } & PC & $.558^{* *}$ & P24PC & $.490^{* *}$ \\
\hline & Sig. & .000 & Sig. & .000 \\
\hline & $\mathrm{N}$ & 76 & $\mathrm{~N}$ & 76 \\
\hline \multicolumn{2}{|c|}{ P10PC } & $.734 * *$ & P25 PC & $.328^{* *}$ \\
\hline & Sig. & .000 & Sig. & .004 \\
\hline & $\mathrm{N}$ & 76 & $\mathrm{~N}$ & 76 \\
\hline \multicolumn{2}{|c|}{ P11 PC } & $.635^{* *}$ & P26PC & $.372^{* *}$ \\
\hline & Sig. & .000 & Sig. & .001 \\
\hline & $\mathrm{N}$ & 76 & $\mathrm{~N}$ & 76 \\
\hline \multicolumn{2}{|c|}{ P12PC } & $.600 * *$ & P27 PC & $.247^{*}$ \\
\hline \multicolumn{2}{|c|}{ Sig. } & .000 & Sig. & .032 \\
\hline & $\mathrm{N}$ & 76 & $\mathrm{~N}$ & 76 \\
\hline \multicolumn{2}{|c|}{ P13 PC } & $.662 * *$ & P28PC & $.440 * *$ \\
\hline \multicolumn{2}{|c|}{ Sig. } & .000 & Sig. & .000 \\
\hline & $\mathrm{N}$ & 76 & $\mathrm{~N}$ & 76 \\
\hline \multicolumn{2}{|c|}{ P14PC } & $.674 * *$ & P29PC & $.520^{* *}$ \\
\hline \multicolumn{2}{|c|}{ Sig. } & .000 & Sig. & .000 \\
\hline & $\mathrm{N}$ & 76 & $\mathrm{~N}$ & 76 \\
\hline \multicolumn{2}{|c|}{ P15PC } & $.680 * *$ & P30 PC & .185 \\
\hline \multicolumn{2}{|c|}{ Sig. } & .000 & Sig. & .109 \\
\hline \multicolumn{2}{|r|}{$\mathrm{N}$} & 76 & $\mathrm{~N}$ & 76 \\
\hline
\end{tabular}

Explanation: PC: Pearson Correlation, Sig (2Tailed)

From all items 1 to 30, items that were declared invalid were P27 (0.032) and P30 (0.109). Both items have a significance of more than 0.05 , so both items are declared invalid. Meanwhile, other items, because they have a significance of less than 0.05 , are declared valid.
Table 8. Reliability test

\begin{tabular}{cc}
\hline Cronbach's Alpha & N of Items \\
\hline .908 & 28 \\
\hline
\end{tabular}

The reliability test results stated that of the total 28 items that were declared valid, they had a limit using Cronbach Alpha of 0.908. This states that the reliability test results obtained are more than 0.6. Then the data is stated to be very high and reliable.

Table 9. Regression test professionalism competence

\begin{tabular}{|c|c|c|c|}
\hline \multicolumn{4}{|c|}{ Coefficients $^{a}$} \\
\hline \multicolumn{2}{|c|}{ Model } & $\mathrm{t}$ & Sig. \\
\hline \multirow[t]{4}{*}{1} & (Constant) & 3.057 & .003 \\
\hline & Management & 4.540 & .000 \\
\hline & educational information & & \\
\hline & system & & \\
\hline
\end{tabular}

\section{a. Dependent Variable: Professionalism}

competence

The $\mathrm{t}$ table can be seen using a statistical table with a significance of $0.05 \div 2=0.025$ with the degree of freedom $\mathrm{df}=\mathrm{n}-2$ known to be $\mathrm{n}$ (76) then 76-2 =74. The results obtained for the $\mathrm{t}$ table are 1.993 (see attachment $\mathrm{t}$ table). The $\mathrm{t}$ count is 4.540 and the $\mathrm{t}$ table is 1.993 (4.540> 1.993). So, Ho is rejected. It concluded that information system management affects professional competence.

Table 10. Regression test pedagogic competence 


\begin{tabular}{|c|c|c|c|}
\hline \multicolumn{2}{|c|}{ Model } & \multirow{2}{*}{$\begin{array}{c}\mathrm{t} \\
4.864\end{array}$} & \multirow{2}{*}{$\begin{array}{l}\text { Sig. } \\
.000\end{array}$} \\
\hline 1 & (Constant) & & \\
\hline & $\begin{array}{l}\text { Management } \\
\text { educational information } \\
\text { system }\end{array}$ & 4.030 & .000 \\
\hline
\end{tabular}

a. Dependent Variable: Pedagogik

competence

The $\mathrm{t}$ table knowing by using a statistical table with a significance of $0.05 \div 2=0.025$ with the degree of freedom $\mathrm{df}=\mathrm{n}-2$ known to be $\mathrm{n}(76)$ then $76-2=74$. The results obtained for the $\mathrm{t}$ table are 1.993 (see attachment $\mathrm{t}$ table). The $\mathrm{t}$ count is 4030 , and the $\mathrm{t}$ table is 1.993 (4030> 1.993). So, Ho is rejected. It concluded that information system management affects pedagogical competence.

\section{Implementation of management} educational information system at MI Muslimat NU Pucang

The researchers conducted questionnaire that distributed to all teachers, direct and online observations and unstructured interviews. In this study, researchers conducted un structured interviews with school head master, represented by the deputy head master, Mrs. Nurul Laili, S.Pd, M.Pd.I. The management of the education information system, in its implementation, the head master uses a blueprint as a plan for the next 2 to 4 years. The blueprint discusses madrasah management and work plans and other supporting management. To maximize information system management, the school holds a small group meeting of teachers where the group contains 1 to 6 teachers to prepare lessons given to students, the media that used, and discuss problem-solving faced by the teacher while in class.

The educational information systems that used include Google meet and SIMAS, SIMAS (madrasah information system) helped facilitate and make it easy for teachers to upload grades, teaching journals, news from teachers, and the teaching and learning process, which parents can access it too. During this pandemic, teachers have optimized the use of Google meet, where teachers will find it easier to meet students face to face. Each learning class team will be accompanied by one supervising teacher in one room meet. As a supporter of the learning process, the teacher gives each student a flash disk containing material in e-books, PDFs, and explanatory videos recorded by the teacher.

Supporters of distance learning at MI Muslimat NU have not used the e-learning system due to limited IT mastery from the school IT team. The school, IT team is currently developing and optimizing SIMAS (madrasah information system). The education information system can provide information to students' parents or guardians about attendance, report cards, and the grades that students get during learning. Besides, SIMAS (madrasah information system) is also used as 
an educational information system that supports teacher performance. Teachers can fill in learning journals, performance journals, and assessments in one integrated system.

Weekly, the teachers, conduct regular performance evaluations with the school principal and a team of teacher supervisors to evaluate the learning process and teacher performance in schools. Also, teachers will provide training related to the optimization of educational information systems to obtain wi-fi facilities in schools to optimize educational information systems.

Picture 2. SIMAS (madrasah information system)

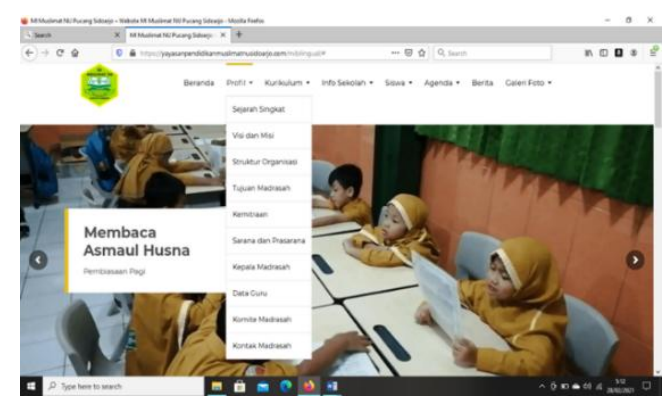

The effect of the application of educational information system management on professional competence and pedagogic competence in MI Muslimat NU Pucang is known through the results of regression test, and the results from the analysis of the results above show that Ho is rejected, it concluded that information system management affects to professionalism and pedagogic competence.

\section{Implementation of management educational information system at SD Muhammdiyah 1}

The researchers used direct and online observation techniques by looking at the school's website page and making direct observations at the SD Muhammadiyah 1 Pucanganom school. Researchers also conducted unstructured or free interviews conducted with Mr. Moh. Syaifullah Rochim, S.E, S, Pd, M.Pd. as the principal and questionnaires distributed to all teachers at SD Muhammadiyah 1 Sidoarjo, totaling 68 teachers.

The implementation of education information system management at SD Muhammadiyah has been well and optimally implemented. In the management process that schools carry out, schools optimize the use of educational information system. The educational information system implemented by schools is in LSM, e-Learning, Zoom meetings, Muhida Radio, and CSM cards. In the education information system management process, the principal mobilizes all teachers to make optimal use of the education information system. Before the pandemic, the education information system was already in use in schools, with about $25 \%$ of the use supporting learning. After the pandemic that occurred in Indonesia, the maximum use of the information system was $100 \%$. 
LSM (Muhammadiyah 1 sidoarjo school web page) is a school website that contains school profiles, e-learning, extras, PPDB, and the school's vision and mission. On this page, teachers and students can access school news and other latest information. At SD Muhammadiyah 1 LSM, this page is integrated with Muhida Belajar (e-learning).

Picture 3. LSM (school web page)

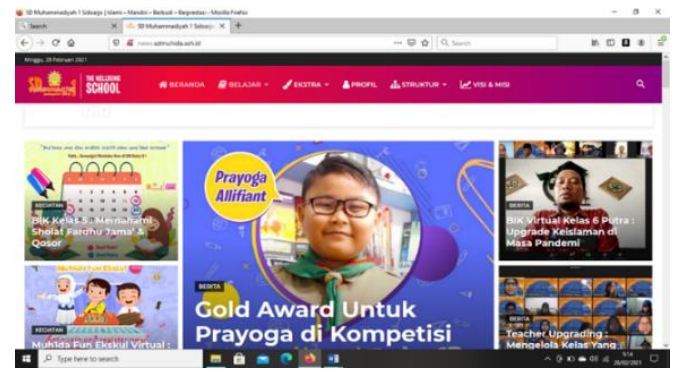

Muhida Belajar (e-Learning) can be accessed 24 hours, and the material that has been uploaded into e-learning can be repeated many times. Students can access and download material that has been uploaded in e-learning. In the management process of using the Muhida Belajar e-learning as educational information system, the principal mobilizes all teachers to provide interesting material by uploading learning videos of each teacher's work. Interesting learning videos where the video contains material and animations created by the teaching teacher. In education information system management, the principal directs all teachers to train both outsides and inside the school. One of the training carried out by the school included training on the use of LSM, e-learning, and making educational videos assisted by KPN Bogor. The school also conducts peer counselors between teachers to help teachers who experience problems in using the education information system.

\section{Picture 4. Muhida Belajar (e-learning)}

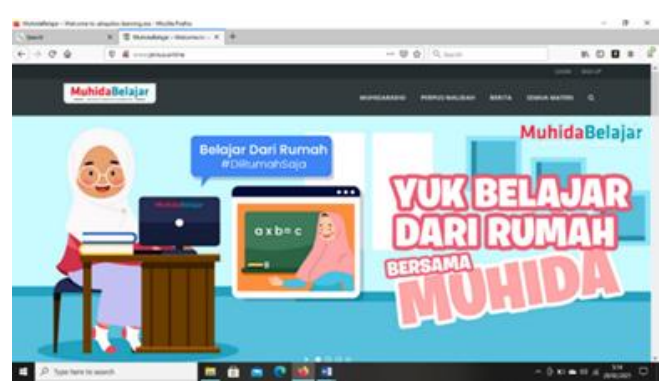

In addition to maximizing the use of LSM and e-learning, the school also optimizes the use of the premium meeting zoom, where the online meeting room will help make it easier for teachers to meet students face to face. The school budgeted funding for the premium zoom meeting, which supports optimizing teaching and learning activities at SD Muhammadiyah 1. Besides, the school also facilitates school wi-fi with a speed of 400 Mbps to maximize online learning for teachers who want to teach from school. The school also facilitates teachers and all students with internet quotas, where the quota will make it easier for teachers and students to do distance learning.

SD Muhammadiyah 1 provides an online application in the form of Muhida Radio. Muhida Radio is an online radio dedicated to online student learning and literacy activities and can be accessed from home and anywhere. 
Through the Muhida Radiosiswa application, the student can listen to various literacy programs via audio. Besides, that students can download or read literacy texts from radio programs simultaneously. In the Muhida Radio application, students can also learn online and listen to the playback of the teacher's explanation when teaching in class.

Picture 5. Muhida Radio

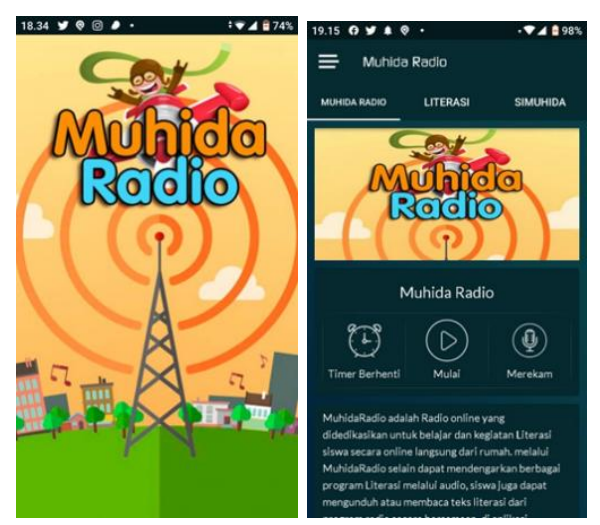

The use of the MSC card is an education information system management that schools carry out. MSC card is a smart card that can function as e-money. MSC cards at SD Muhammadiyah 1 school are distributed to teachers/employees and students. Through the MSC card, teachers can attend attendance and be used from home, borrow books at the library, and make transactions at school cooperatives, considering that the MSC card can be used as e-money. Besides that, the MSC card designated for teachers will also develop to obtain licensing for teachers. Share the MSC cards given to students. The card can be used as the presence of students connected to WhatsApp teachers and parents, as to borrow cards in libraries, and as e-money to be used for transactions in canteens and cooperatives.

Picture 6. MSC Card

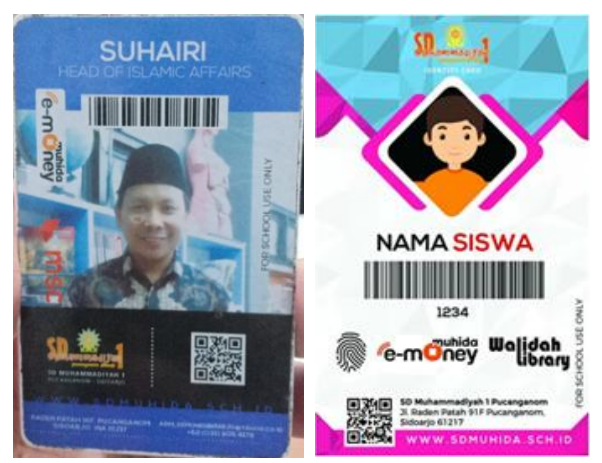

The effect of the application of education information system management on professionalism and pedagogic competence at SD Muhammadiyah 1 Pucanganom, through the questionnaires distributed to teachers at SD Muhammadiyah 1, is known that the regression test results from the data analysis above that Ho is rejected, it concluded that information system management affects professionalism and pedagogical competence.

This is also supported by interviews conducted by researchers with the head master Mr. Moh. Syaifullah Rochim, S.E, S, Pd, M.Pd., where the head master stated that management educational information system help teachers and facilitate the teacher's duties as a teacher. Also, the management of the education information system implemented in schools is expected to improve the core competencies of teachers. Two of these core competencies are professionalism and pedagogical competencies. Management of 
information systems in the form of CSM cards is carried out to increase professional competence because the school assesses that the better the rewards and convenience gave to teachers, the better the competence of teachers.

\section{RESULT}

The data analysis described in the previous chapter shows that the regression test results from the analysis of the results above show that the $\mathrm{t}$ value in the table is 1.993 and the $\mathrm{t}$ count is 4.540 for professional competence. So it concluded that $(4,540>1,993)$ that $\mathrm{Ho}$ is rejected and $\mathrm{Ha}$ is accepted, it concluded that information system management affects professional competence. It is known that the $t$ count for pedagogic competence is 4.030 , and the $t$ table is 1.993 then $(4.030>1.993)$. So, it concluded that $\mathrm{Ho}$ is rejected and $\mathrm{Ha}$ is accepted. It concluded that information system management affects pedagogical competence. The results obtained through data collection techniques from MI Muslimat NU and SD Muhammadiyah 1 have similarities. Still, there are differences where the information system management implemented at SD Muhammaidyah 1 uses a more diverse education information system, maximizes its application. Its implications for teachers' competence, professionalism, and pedagogic are also supported by the school's aim, where the SD Muhammadiyah 1 school aims to become a digital school in this digital era.

\section{REFERENSI}

Aji, R. H. S. (2020). Dampak Covid-19 pada Pendidikan di Indonesia: Sekolah, Keterampilan, dan Proses Pembelajaran. SALAM Jurnal Sosial \& Budaya Syar-I, 7(5), 395-402. https://doi.org/10.15408

Aslan, A., Silvia, S., Nugroho, B. S., Ramli, M., \& Rusiadi, R. (2020). Teacher'S Leadership Teaching Strategy Supporting Student Learning During the Covid-19 Disruption. Nidhomul Haq: Jurnal Manajemen Pendidikan Islam, 5(3), 321-333. https://doi.org/10.31538/ndh.v5i3.98 4

Asmani, J. M. (2009). 7 Kompetensi Guru Menyenangkan dan Profesional. Power Book (IHDINA).

B. Uno, Hamzah \& Lamatenggo, N. (2010). Teknologi Komunikasi dan infromasi pembelajaran. PT Bumi Akasara.

Barizi, A. (2009). Menjadi guru unggul. Ar-Ruzz Media.

Demirkasimoğlu, N. (2010). Defining 'teacher professionalism' from different perspectives. Procedia - Social and Behavioral Sciences, 9, 2047-2051. https://doi.org/10.1016/j.sbspro.2010 .12 .444

Echeverría, M. A. M., Santana-Mancilla, P. C., \& Cazares, V. M. D. la R. (2012). An Educational Management Information System to Support Institutional Planning at the University of Colima. Procedia - Social and Behavioral Sciences, 55, 1168-1174.

https://doi.org/10.1016/j.sbspro.2012 .09 .611

Fattah, N. (2013). Analisis Kebijakan Pendidikan. PT Remaja Rosdakarya. 
Firma Sahrul B, M. A. S. O. D. W. (2017). Implementasi Sistem Informasi Akademik Berbasis Web Menggunakan Framework Laravel. Jurnal Transformasi, 12(1), 1-4.

George Saadé, R. (2013). Web-Based Educational Information System for Enhanced Learning, EISEL: Student Assessment. Journal of Information Technology Education: Research, 2, 267277. https://doi.org/10.28945/327

Hartono. (2011). Pendidikan Integratif. STAIN Press.

Imtihan, K. (2015). Perencanaan Strategi Sistem Informasi Pendidikan Pada Sekolah Tinggi Manajemen Informatika dan Komputer ( STMIK ) Lombok. 3(2), 73-78.

Ismail, S., Zahrudin, M., Ruswandi, U., \& Erihadiana, E. (2020). The Competence of Millennial Islamic Education Teachers in Facing The Challenges of Industrial Revolution. Nąhruna: Jurnal Pendidikan Islam, 3(3), 389-405.

https://doi.org/10.31538/nzh.v3i3.82 3

Kunandar. (2009). Guru Profesional Implementasi Kurikulum Tingkat Satuan PendidikanNo Title. PT Raja Grafindo Persada.

Leonard, L. (2016). Kompetensi Tenaga Pendidik di Indonesia: Analisis Dampak Rendahnya Kualitas SDM Guru dan Solusi Perbaikannya. Formatif: Jurnal Ilmiah Pendidikan MIPA, 5(3), 192-201. https://doi.org/10.30998/formatif.v5i 3.643

Luan, W. S., Atan, H., \& Sabudin, S. (2010). Exploring teachers' perceptions of their pedagogical role with computers: A case study in Malaysia. Procedia -
Social and Behavioral Sciences, 2(2), 388391.

https://doi.org/10.1016/j.sbspro.2010 .03 .031

Maqsood, A., Abbas, J., Rehman, G., \& Mubeen, R. (2021). The paradigm shift for educational system continuance in the advent of COVID-19 pandemic: Mental health challenges and reflections. Current Research in Behavioral Sciences, $\quad 2, \quad 100011$. https://doi.org/10.1016/j.crbeha.2020 .100011

Muhaimin. (2012). Pemikiran dan Aktualisasi pengembangan pendidikan Islam. Rajawali Press.

Munjiat, S. M. (2020). Implementation of Islamic Religious Education Learning in Higher Education on The Pandemic Period. Naz̧bruna: Jurnal Pendidikan Islam, 3(2), 285-295. https://doi.org/10.31538/nzh.v3i2.75 7

Musfiqon. (2012). Metodologi penelitian pendidikanNo Title (First). PT. Prestasi Pustaka.

Noraziah, A., Fauzi, A. A. C., Deris Mat, M., Saman, M. Y. M., Zain, N. M., \& Khan, N. (2011). Managing educational resource-student information systems using BVAGQ fragmented database replication model. Procedia - Social and Behavioral Sciences, 28, 127-132. https://doi.org/10.1016/j.sbspro.2011 .11 .026

Nurulloh, A., Aprilianto, A., Sirojuddin, A., \& Maarif, M. A. (2020). The Role of the Head of Madrasah'S Policy in Improving Teacher Professionalism. Nidhomul Haq: Jurnal Manajemen Pendidikan Islam, 5(3), 334-346. 
https://doi.org/10.31538/ndh.v5i3.96 3

Pakpahan, P. L., \& Habibah, U. (2021). Manajemen Program Pengembangan Kurikulum PAI dan Budi Pekerti dalam Pembentukan Karakter Religius Siswa: Management of IRE Curriculum Development Program and Character in Forming Student's Religious Character. Tafkir: Interdisciplinary Journal of Islamic Education, 2(1), 1-20. https://doi.org/10.31538/tijie.v2i1.19

Prasojo, L. D. (2013). Penerapan Sistem Informasi Manajemen Pendidikan. https://doi.org/10.31227/osf.io/5arw e

Rochaety, E. (2011). Sistem Informasi Manajemen. Mitra Wacana Media.

Sayed, B. T., Al Mushikhi, K. M., \& Dhanasekaran, B. (2018). Knowledge Based Information System to Manage Transfer of Credits in An Outcome Based Higher Educational Setting. Procedia Computer Science, 154, 26-32. https://doi.org/10.1016/j.procs.2019. 06.006

Sirotová, M. (2016). Pedagogical Praxis as a Process of Developing Professional Competencies in University Education of Future Teachers. Procedia - Social and Behavioral Sciences, 228(June), 529-534. https://doi.org/10.1016/j.sbspro.2016 .07 .081

Sonhaji, A. (2014). Manusia, Teknologi, dan Pendidikan Menuju Peradaban Baru (first). UM PRESS.

Sutabri, T. (2012). Konsep Sistem Informasi (I. Nastiti, Ed.). Andi Offset.

Syar'i, A. (2005). FILSAFAT PENDIDIKAN ISLAM. Pustaka Firdaus, 1(14), 2-132.
UU RI No 14 Thn tentang guru dan dosen. (2005). In Undang-Undang RI Nomor 14 (p. 4).

Van Dyk, E. C., Van Rensburg, G. H., \& Janse van Rensburg, E. S. (2020). Professional virtues foster trust in teaching and learning environments. International Journal of Africa Nursing Sciences, 13(May 2019), 100211. https://doi.org/10.1016/j.ijans.2020.1 00211 